\title{
Assessing Land Use / Land Cover Changes Using GIS and Remotely Sensed Techniques (RST): A Case Study of the Etoa Clay Quarry Yaounde, Cameroon
}

\author{
Linda Lekuna Duna ${ }^{1,4,}$, , Nzeukou Nzeugang Aubin², Fen Florence Fombutu ${ }^{3}$, \\ Pierre François Djocgoue ${ }^{4}$ \\ ${ }^{1}$ Department of Research, Ministry of Scientific Research and Innovations/Local Material Promotion Authority, Yaounde, Cameroon \\ ${ }^{2}$ Department of Earth Sciences, University of Maroua, Maroua, Cameroon \\ ${ }^{3}$ Department of Geography, University of Yaounde 1, Yaounde, Cameroon \\ ${ }^{4}$ Department of Plant Biology, University of Yaounde 1, Yaounde, Cameroun
}

Email address:

lekunali@gmail.com(L. L. Duna),nzeuk@yahoo.fr (N. N. Aubin), flostyfen@gmail.com (F. F. Fombutu), pfdjocgoue@yahoo.fr (P.F. Djocgoue)

${ }^{*}$ Corresponding author

\section{To cite this article:}

Linda Lekuna Duna, Nzeukou Nzeugang Aubin, Fen Florence Fombutu, Pierre François Djocgoue. Assessing Land Use / Land Cover Changes Using GIS and Remotely Sensed Techniques (RST): A Case Study of the Etoa Clay Quarry Yaounde, Cameroon. International Journal of Environmental Monitoring and Analysis. Vol. 9, No. 2, 2021, pp. 45-53. doi: 10.11648/j.ijema.20210902.13

Received: March 16, 2021; Accepted: April 1, 2021; Published: April 29, 2021

\begin{abstract}
This study highlights the use of Remote Sensing to detect environmental changes obtained on Land Use / land Cover Changes in the Etoa clay quarry, neighboring the town of Yaounde (Cameroon) during a period of 26 years (1989-2015). Remotely sensed data in the form of Landsat image and pattern classification were used to create maps. For accuracy Google Earth was used as a reference to yield data. The post classification change detection method was used to value the land cover change with the clay quarry. Land use of the urban growth was estimated by time series analysis of satellite Landsat images. Spectral indices calculated from the images were used to evaluate change in buildup area, vegetation and hydrology. Results show that vegetation, covers 200 hectares of land, build up area 240 hectares and hydrology 185 hectares. The change analysis between 1989-2015 showed a decreasing trend in vegetation from $69 \%$ to $32 \%$ (a decrease in $37 \%$ vegetation cover), hydrology from $14 \%$ to $30 \%$ (thus a $16 \%$ increase in water bodies) and build up area from $17 \%$ to $38 \%$ (a $21 \%$ increase). The excavation of clay materials increases every year leaving behind many dangerous clay pits filled with water which calls for concern.
\end{abstract}

Keywords: Land Use / Land Cover Change, Geographic Information System, Remote Sensing, Image Classification, Clay Quarry, Yaounde

\section{Introduction}

Mineral resources are a major source of raw materials for an industry and it is an essential component of modern-day development by adding on to the economy and the national wellbeing [1]. Today there is a great increase in the world's population which also leads to great increase in the demand for raw materials used in building and construction. This human activities on land generate changes on the earth's surface (land cover). In this regards, land use / land cover change (LULCC) is the transformation of the land or replacement of one land cover type on the earth's surface and it is also an outcome of natural and socio-economic aspects and their operation by human in time and space [2, 3] Land cover refers to the biophysical coverage of land (crops, grass, broad-leaved woods, or built-up areas) while Land use indicates the socio-economic use of land (agriculture, forestry, recreation or residential use) [4, 5, 6, 7]. Forest vegetation and land use / land cover changes have been defined as the Spatial and structural changes in the form of forest degradation and depletion, reducing the forest density 
and species diversity and the extension of arable land and other land use types inside the natural cover after its disturbance $[8,9]$ Land use refers to the manner in which human beings exploit the land and all its natural resources such as agriculture, urban development, gazing, logging and mining [2]. As the world's population grew, the need for more resources also increased [10]. The extraction of natural resources usually generates environmental impacts on water systems, natural vegetation, agricultural land and other natural resources $[5,6,11]$. The increase in human activities over the years cause many environmental impacts on water, air and land. The increase in industrial and mining activities by man has result to environmental degradation which caused flooding in the quarry area, loss of land, deforestation and land degradation. These negative impacts on our environment have drawn a lot of attention on a global scale [12]. Through quarrying activity, many jobs openings have been created and the raw material extracted from the quarry is used for building and construction. However, although these activities constitute an important pillar of economic sustainability, quarrying is a short-term action with long term impacts affecting soil, water, and other natural resources, not to mention the negative effects on human health [13]. The Etoa clay area is rapidly urbanising and the rapid population growth is gradually converting the forest area around this quarry into large artificial environments. During the extraction process of raw materials (clay), heavy duty vehicles are used for the extraction procedures, thereby leaving behind larger clay pits which are left widely open. This clay pits gradually enlarges over the years which becomes larger water surfaces. These clay pits filled with water are exposed and are more dangerous to the inhabitants of this area. The houses of many inhabitants in this area are about $300 \mathrm{~m}$ away from the clay quarry. Mining of clay material in the Etoa clay quarry was first initiated by the local population using local manpower to meet their daily needs. The mining activities in this area was being carried out at local levels alongside with farming activities. The different types of crops that were grown in the area include, maize, beans, cassava, plantains, Cocoyams, vegetables, and cash crop like cocoa. Due to the rapid growth of the urban population, the exploitation of clay material in this area increased greatly thereby reducing the valuable portion reserved for farm land. The main mineral extracted in this study area is clay, which is used to produce burnt bricks, decorative bricks and in turns used in construction of houses. The use of mapping to monitor the environmental changes that occurred in this extraction quarry was then an important tool for assessment. As a result, remotely sensed data has become a useful tool to complement ground-based environmental monitoring methods that are otherwise confined to point, grid or traverse-based measurements [11]. In this study remote sensing method was used to evaluate the land use and land cover changes of the Etoa clay quarry. Remote sensing is a useful tool to detect land use and land cover and other changes within a given quarry area $[4,7,9$, 14]. It is also used for monitoring the activities over many years in a particular area and to bring out the environmental impact of the study area. This was used because it's a method that covers a large surface area and can reach inaccessible areas $[11,15]$. It provides a relatively low cost means of data acquisition method [16]. It was mostly used in the evaluation of environmental impact assessment since it provides existing historical data thus it allows for a long-term series data analysis [17]. One of the environmental impacts in this area is the presence of noise, deforestation, and land degradation, flooding and land pollution. The land was polluted with oil from the heavy duty vehicles during the extraction period. These heavy machines destroy the vegetation cover of the quarry before proceeding with the exploitation. The presence of open clay pits exposed by the heavy-duty vehicle provides a potential environmental negative impact to the inhabitants of this area. In view of the above impacts, this research seeks to explain and demonstrates the application of remote sensing technique as a useful tool to detect Land use and Land cover changes from the Etoa clay quarry. The land use and land cover were evaluated in this area using the remote sensed method from maps of 1989 to 2015 to bring out the landsat image of Etoa clay quarry. Their evolution, vegetation cover, build up area and hydrology of the area were studied.

\section{Study Area}

Yaounde, the political capital of Cameroon is situated in the equatorial zone. Geographically it is situated between latitude $3^{\circ} 52^{\prime} \mathrm{N}$ and longitude $11^{\circ} 31^{\prime} \mathrm{E}$. The site of the clay quarry is situated in the locality of Etoa in Yaounde III SubDivision. It is situated some $4 \mathrm{~km}$ in the south west of Yaounde town and found between the valley of river Mfoundi in the north and river Mefou in the south of Yaounde town and along the Yaounde-Douala high ways. It is found at an altitude of $720 \mathrm{~m}$ and lies NW-SE, forming a Vshape towards the Mefou-Mfoundi confluence. The drainage is convex with gradient that varies between 1 and 5\% [18]. Located in the center region of Cameroon, the Etoa clay quarry lies between the southern dense equatorial rainforest and the central forest region within latitudes $3^{\circ} 46^{\prime} 19$ and $3^{\circ} 46^{\prime} 22.86$ north and longitude $11^{\circ} 28^{\prime} 50.68^{\prime \prime}$ and $11^{\circ} 28^{\prime} 54$ and along the bangs of river Mefou. The study area covers a surface area of 288.81 hectares. The zone retained for the extraction of clay materials is 5 hectares. This quarry area is currently endowed or enriched with clay material thus making it an ideal source of quarry activities operations. Due to its vast geological view of clay material of 288.81 hectares, there has been an emergence of the local population and the other companies to carry out intensive activities of extracting clay in the recent years. The clay material in this area was mostly collected by the local population and some companies who deal with the production of local materials for the use in construction of houses. This quarry operates close to the human settlement of the community and it possess a serious negative environmental impact and health risk. The presence of the continuous exploitative activities of 
clay material in the Etoa clay quarry shows a great environmental impact on land use and land cover activities.

\section{Materials and Methods}

The study area is covered by the landsat image for two years $(1989,2015)$. Materials used included geographic positioning system (GPS), questionnaires for data collection and data analyses, software such as ERDAS imagine for satellite image processing and Quantum GIS for extraction and data analyses.

\subsection{Maps Selection and Image Analysis}

Maps of required zones were obtained from the National Institute of Cartography (INC) as from 1989 and 2015 which gives the great change for over 26 years. The maps were collected and the study area delineated based on limits. The manipulation, extraction, spatialization and data analyses of the digital image was done using Arc GIS 10.2.1 and Quantum 2.8.1, whereby the geometry was corrected and calibrated from field values. Visual interpretation led to false colour composition and assigning the zone of interest leads to training site identification. Maximum likelihood classification was done which gave supervised classification and post classification process. Separability test was also done in conformity to the Global positioning system (GPS) reading collected from field work and ground verification was done. Way points and lines were collected using a Global positioning system (GPS) receiver and the waypoints collected represents pillars, buildings, water bodies while linear data represents roads tracks and boundaries.

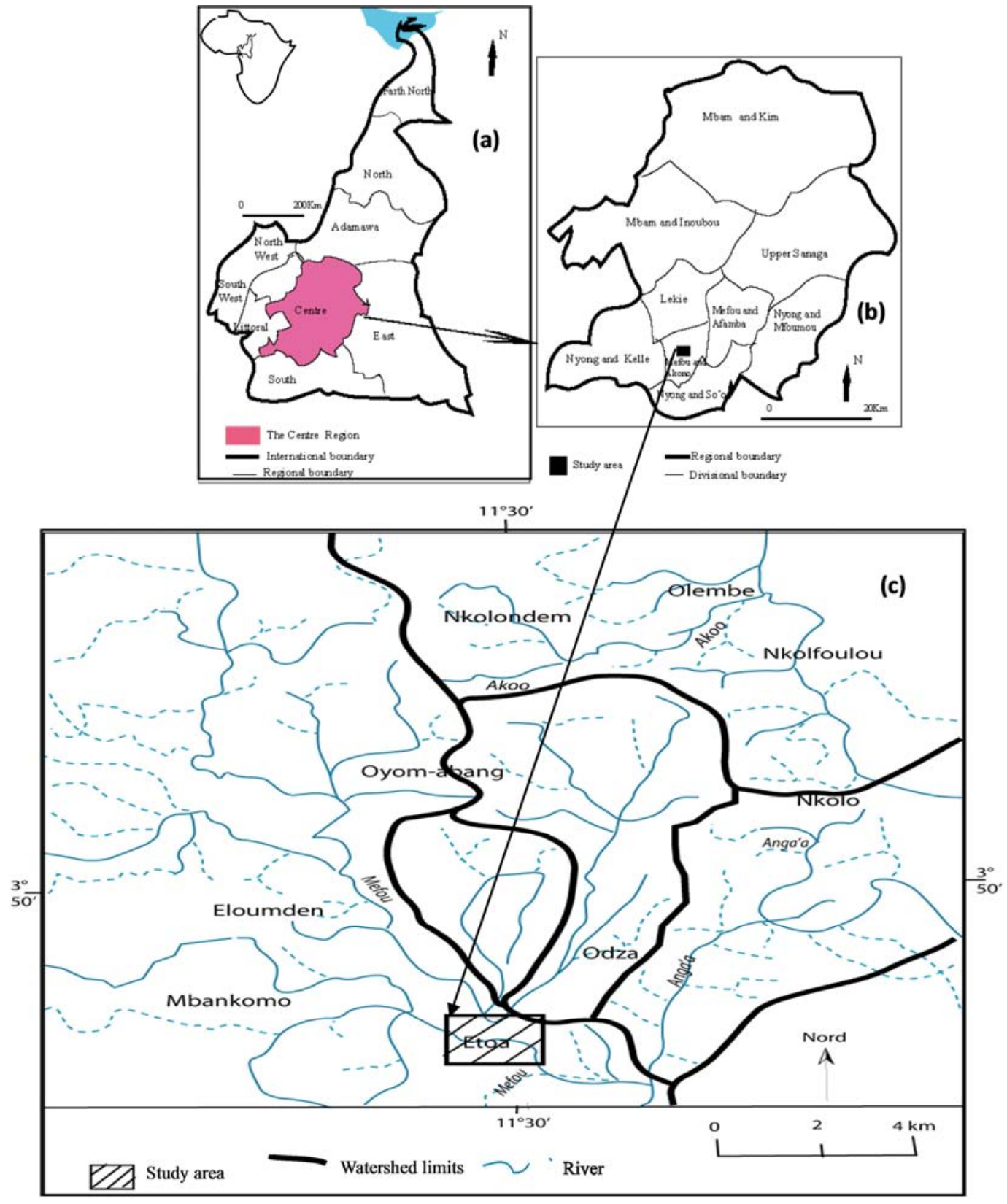

Figure 1. Localization of studied area (a: Yaounde in Cameroon, b: Center region, $c$ : Etoa in the Mefou watershed). 


\subsection{Data Processing}

GPS data: Waypoints and tracks were collected using a Garmin GPS device. After collecting these data, they were downloaded through map source, converted to shape files in quantum GIS and then displayed as layers in ArcGIS. The data were corrected, processed and integrated on data extracted from the satellite image to have an update of the land use activities of the quarry area. Information gathered through interviews, observations, questionnaires and from the maps of 1989 and 2015 were analysed using spread sheet program (Microsoft word 2010, Excel 2010, Quantum geographic information system (QGIS 2.8.1 and ERDAS imagine) to come out with maps, averages, percentages, tables and others. The exploitation of topographic maps of the area, satellite image visualization, interpretation, processing and digitalization were used to extract the different land use elements. The obtained data were classified into the different types of land use and land cover elements such as the vegetation, hydrology, build up area and each covered area has similar spectral properties.

\subsection{Classification of Images from 1989 to 2015}

Extraction through supervised classification was done using the false colour composition of the image into four classes of interest in terms of land cover and land use variability and evolution. This classification permitted an appreciation of dynamics in land cover and land use in the quarry area. Both supervised and unsupervised classifications were done. The supervised classification was done for 1989 and 2015. After this classification, the resulting images were exported to Arc GIS 10.2.1 for layout. This was based on the statistics of training areas representing different ground objects selected. Spectral signatures of different features including (urban area, vegetation, build up, bare soil) were analyzed to identify unique pattern in each land cover to develop new indices. Spectral signatures analysis of various land covers shows better separation of these classes.

\section{Results and Discussion}

\subsection{Characteristics of the Respondents and Landsat Image Analyses}

Most of the inhabitants of Etoa and its environs are origins of the center region, the Yandas (about $70 \%$ of respondent) and are owners of land and houses. The present land of the clay quarry is owned by the natives of this zone. The analysis of the 1989 and 2015 maps of this zone shows that since the start of the exploitation of clay in this zone, there has been some environmental degradation.

\subsection{Assessment of LU/LC Change Between 1989 and 2015}

\subsubsection{Initial State of Etoa and Its Environs Before Exploitation (1989)}

Before the exploitation of clay quarry in this area, this zone was considered as a natural area with the presence of high cover of vegetation, low build up houses and hydrological network intact. After the analyses of the map of 1989 which was before the start of the clay exploitation in this zone it was discovered that, out of the 288.81 hectares of total surface area, vegetation cover was 400 hectares, build up area was 100 hectares and hydrology was 80 hectares (Figure 5) and the correspondent histogram was shown in Figure 6.

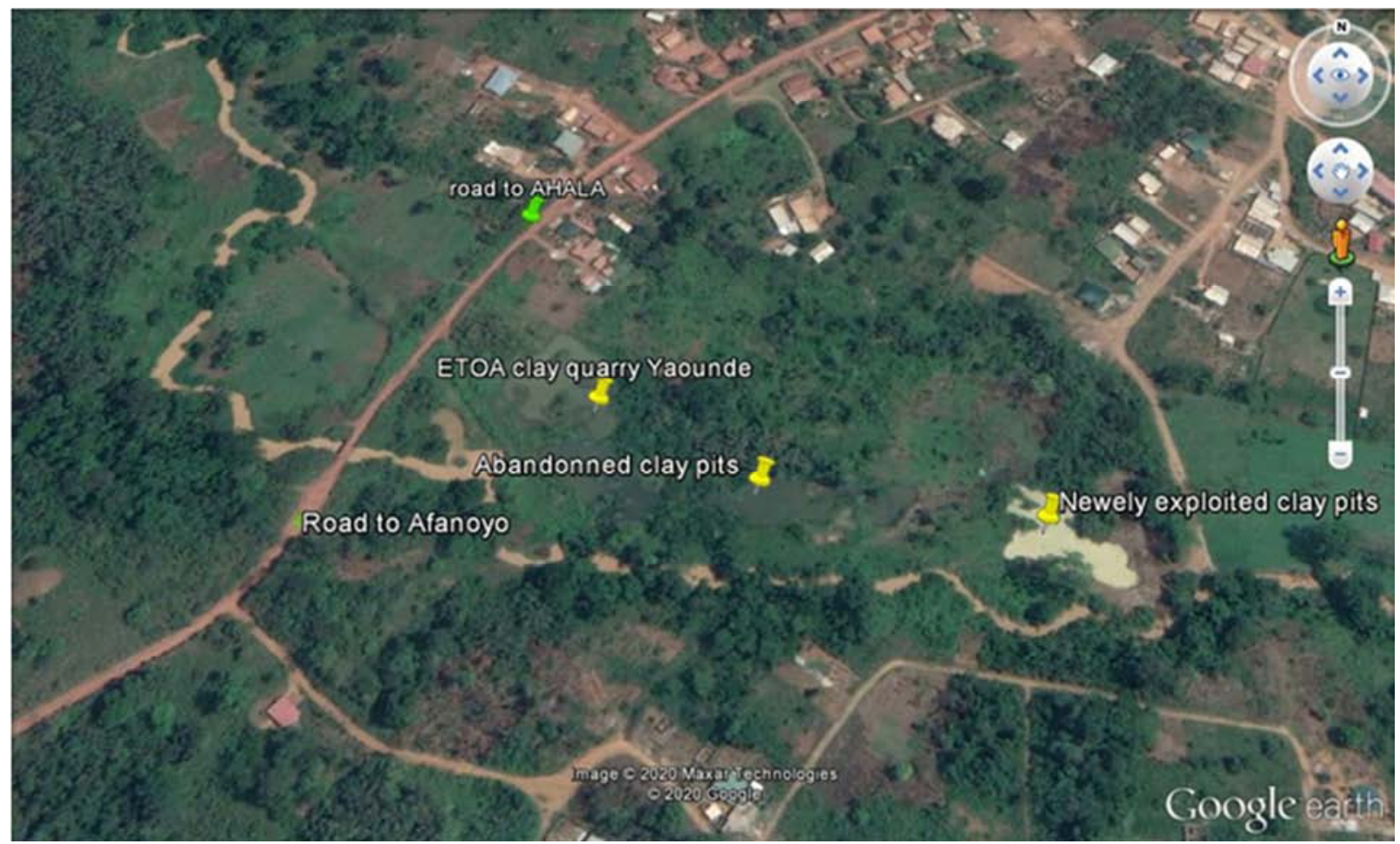

Figure 2. Google Earth image showing the Etoa clay quarry in Yaounde. (Source, Google Earth). 


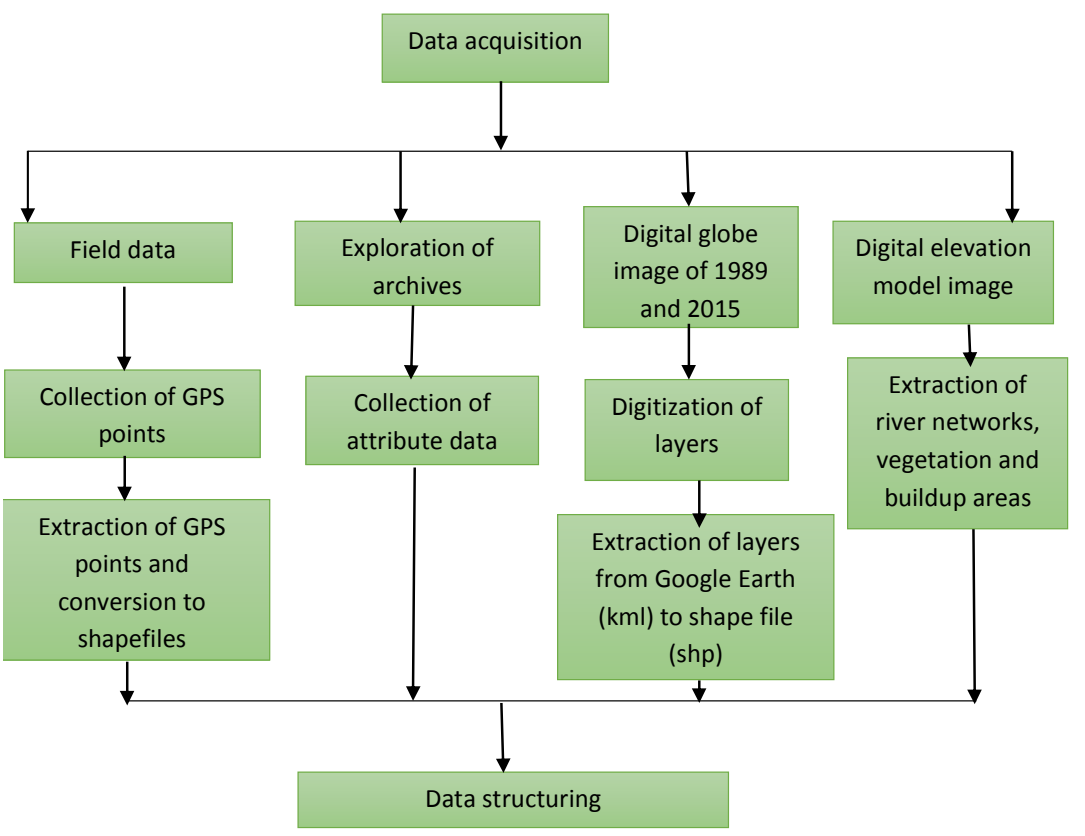

Figure 3. Flow diagram of data acquisition.

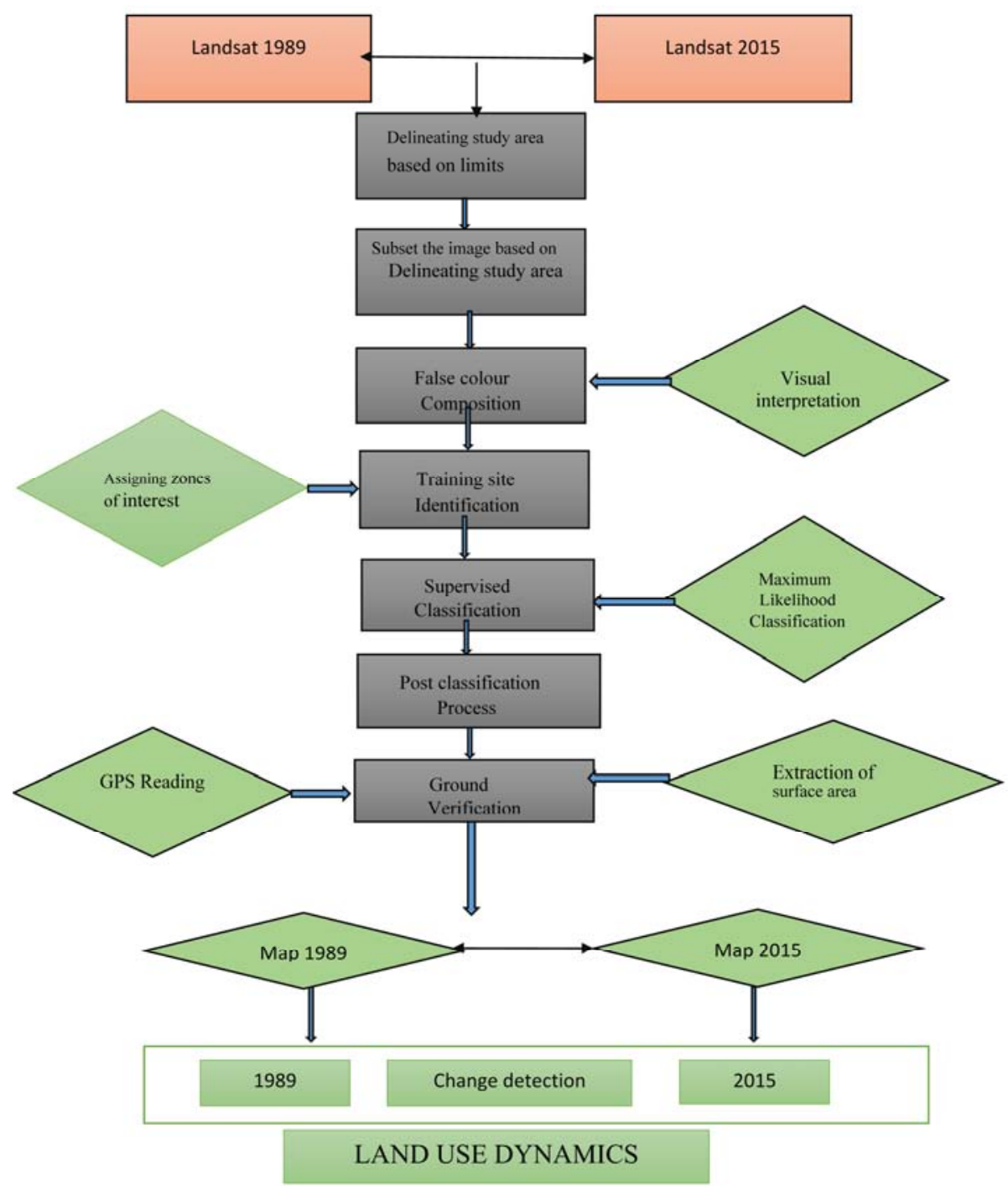

Figure 4. Flow chart for land used dynamics for 1989 and 2015. 


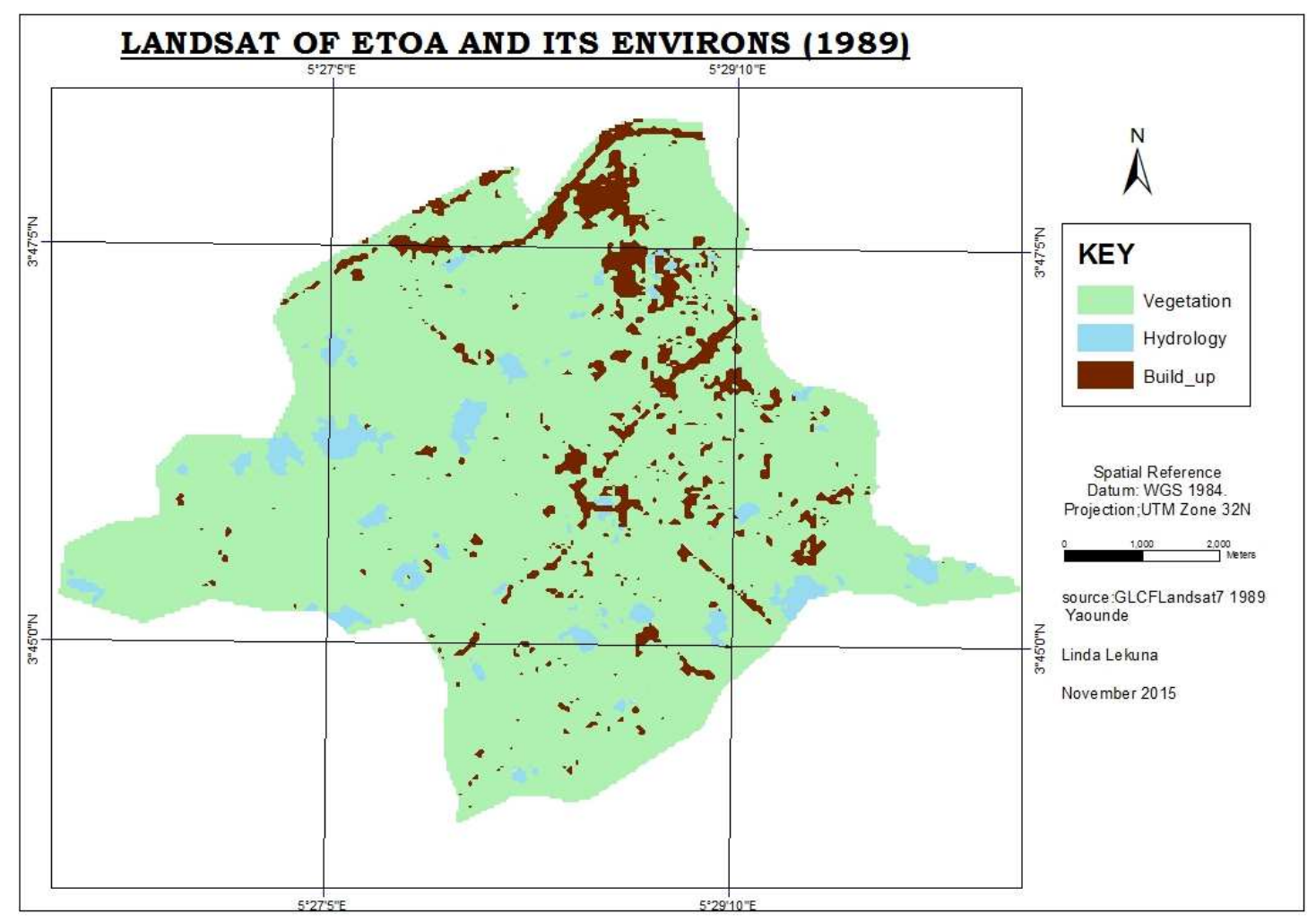

Figure 5. Landsat image of Etoa and its environs (1989).

\subsubsection{Present Situation of Etoa and Its Environs (2015)}

The analyses of the area with the present exploitation of clay material permits to bring out all the possible impacts that are generated by the clay exploitation to its immediate environment. The environmental component analysed is the physical, biological and the socio-economic milieu. The study area is analysed using the remotely sensed method of analysing the map of 2015 . Vegetation cover shows that it covers 200 hectares of land, build up area covers 240 hectares of land and hydrology covers 185 hectares of land. Land use of the urban growth is estimated by time series analysis of satellite Landsat images. Spectral indices calculated from the images are used to evaluate change in buildup area, vegetation and hydrology. Due to rapid urban growth in developing countries (i.e Cameroon), build up areas have been dramatically expanded to suburban area, generally called "peri-urban zones" consequence of the rural-urban migration $[4,5,6]$. From the comparison between the time series Landsat images of 1989 and 2015, many vegetated areas and bare ground area of the 1989 images are changed to build up areas in the 2015 newer images (Figure 8).

Vegetation cover has reduced from $69 \%$ to $32 \%$ causing a great loss of biodiversity, hydrology increases from $14 \%$ to $30 \%$ as excavation of clay materials increases every year leaving behind many clay pits filled with water. Build up area increases from $17 \%$ up to $38 \%$ as the population also increases and this is a factor that should not be neglected in the analysis of socio-economic data. The inhabitants of this zone (the Yandas) practice subsistence agriculture, based on the production of food crops for local consumption and not for exportation. Agriculture constitutes the principal source of revenue, hence expropriating people on a land of 5 hectares will be a handicap to the population of this locality if appropriate measures are not taken.

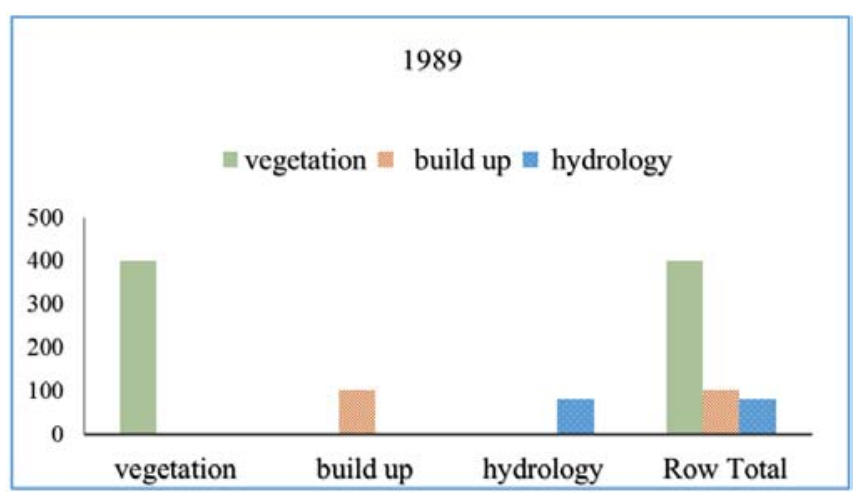

Figure 6. Evaluation of vegetation cover, build up area and hydrology of Etoa and its environs in 1989.

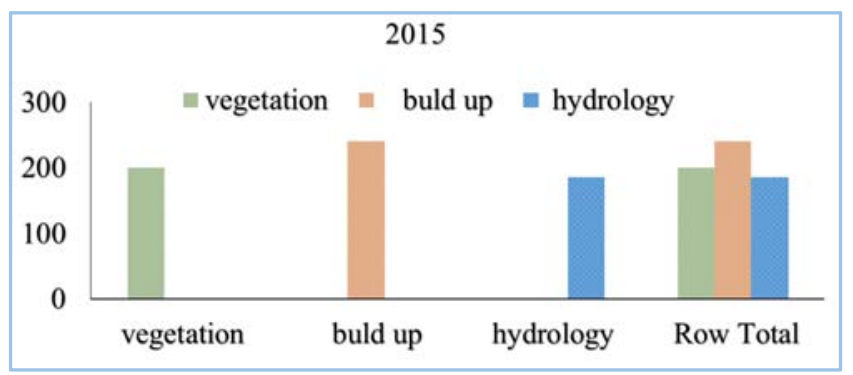

Figure 7. The evaluation of vegetation cover, build up area and hydrology of Etoa and its environs in 2015. 
LANDSAT OF ETOA AND ITS ENVIRONS (2015)

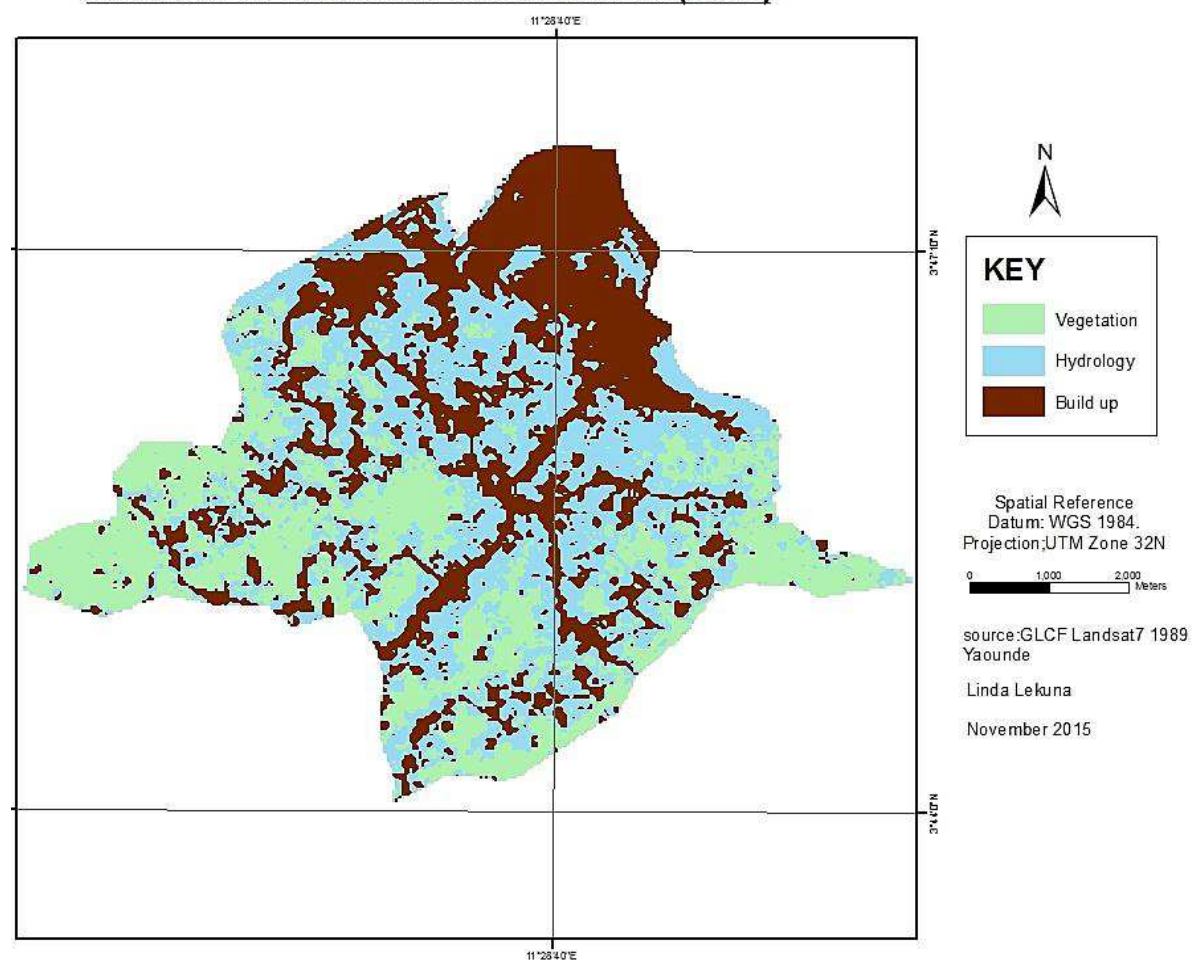

Figure 8 Landsat image of Etoa and its environs in 2015.

The presence of this clay pits is just about $5 \mathrm{~m}$ away from the river Mefou which joins to the River Mfoundi and goes round to Mbalmayo where it is captured and treated as source of drinking water to the population of Yaounde town. Exploitation of clay here is done in a disorderly way making the zone a risk zone. Heavy woods are destroyed including the destruction of raphial palm found in the area. Figure 7 shows the results from the evaluation of the land use pattern in the Etoa and its environs on various components of the environments (vegetation, buildup and hydrology) on the present situation.

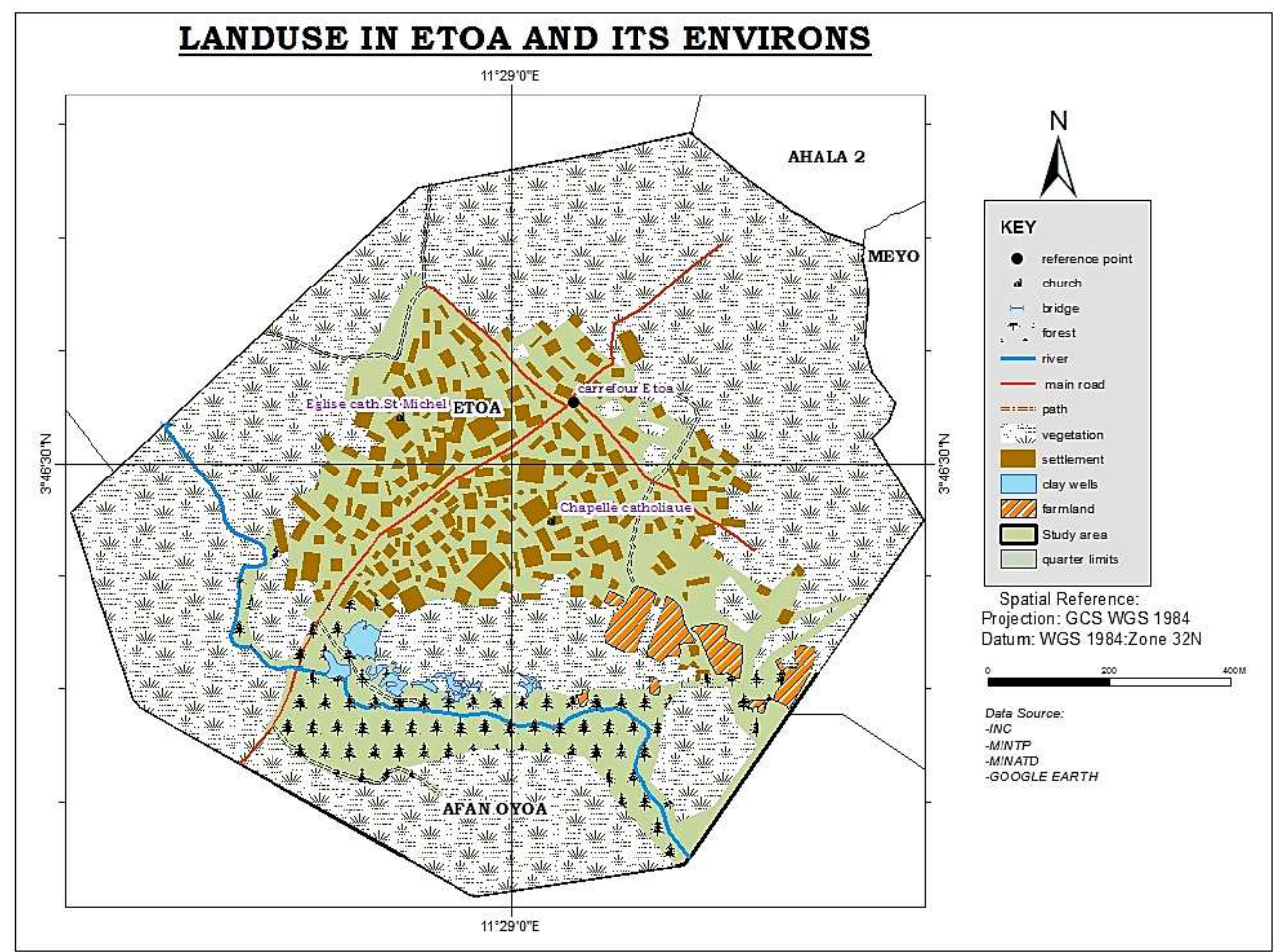

Figure 9. Land use pattern of Etoa and its environs (2015). 


\subsection{Evaluation of Land Use Pattern Areas}

The evaluation of the land use pattern (vegetation, build up and hydrology) shows a great change in the different environmental components. Vegetation has drastically reduced due to deforestation and human activities. According to [6] these changes occur monthly or yearly due to the extent of the intensity of land use, linked to economic development and population growth. Build up area (houses, roads, schools,...) has increased while the high demand for clay material for burnt bricks has also lead to the increase in excavation of clay and consequently an increase in the water surface in this area. Table 1 shows the various percentage change in the different environmental components from 1989 to 2015 .

Spectral indices calculated from the combination of multibands images have been widely used to calculate vegetated and bare ground area in remote sensing technology. The normalized difference vegetation index (NDVI) which is one of the powerful indices to evaluate vegetated areas in satellite images is used. Figure 9 shows the land use in Etoa and its environs of 2015 . The percentage change is $-37 \%$ for the vegetation, $+21 \%$ for buildup and $+16 \%$ for hydrology. Those variations over specific periods, in land use/cover studies, are very helpful in land management strategies. LULC changes studies can enable resource managers to predict change scenarios helpful of environmentally-friendly policies to improve natural resources sustainability $[4,5,6]$.

Table 1. Percentages of land use of 1989 and 2015 in Etoa and its environs (NDVI index).

\begin{tabular}{|c|c|c|c|}
\hline Year Component & Vegetation & Build up & Hydrology \\
\hline 1989 & $69 \%$ & $17 \%$ & $14 \%$ \\
\hline 2015 & $32 \%$ & $38 \%$ & $30 \%$ \\
\hline 1989-2015 (percentage change) & $-37 \%$ & $+21 \%$ & $+16 \%$ \\
\hline
\end{tabular}

\section{Conclusion}

In this study the impact of the clay quarry on the surrounding environment within 288.81 hectares of land using GIS and remote sensing techniques (RST) was used. It was also proven that the supervised classification of the satellite images of 1989 and 2015 was effectively used to quantify and characterized changes of land use and land cover in the surrounding Environment. Landsat image for 1989 and 2015 were used to carryout Remote Sensing image analysis. The experimental results obtained in this research demonstrated that remote sensing is a valuable tool in detecting land cover changes in the Etoa clay quarry area. Vegetation cover, build up area and hydrology with similar spectral could be easily identified and separated due to pattern classification as concern unpattern classification whereby features are not easily identified. From the analysis, there was a significant loss of vegetation cover by $37 \%$, increase in buildup areas by $21 \%$ and an increase by $16 \%$ in hydrology from 1989 to 2015. The significant loss of vegetation cover is attributed to the human activities going on in the area for the extraction of clay material and the increase in hydrology is due to degradation of the environment of the increase digging of the clay pits filled with water. From these results, it could be concluded that the extraction of clay material in the Etoa clay quarry could impact the environment negatively just like any other mining activity. LULCC studies are useful tools in land management strategies to improve sustainability of natural resources, quantify and characterized the LULC.

\section{Conflicts of Interest}

The authors declare that there are no conflicts of interest.

\section{References}

[1] Ugyen Tshewang., 2012. Environmental Assessment Guideline for Mines and Quarries.

[2] Halah Q. H. and Osamah H. M., 2020. Land Cover Change Detection in Al-Karkh / Baghdad. International Journal of Science and Research (IJSR), Vol 9, Issue 1, pp 412-417.

[3] Dires Tewabe, Temesgen Fentahun., (2020) Assessing land use and land cover change detection using remote sensing in the Lake Tana Basin, Northwest Ethiopia, Cogent Environmental Science, 6: $1, \quad 1778998$. https://doi.org/10.1080/23311843.2020.1778998.

[4] Selçuk Reis, 2008. Analyzing Land Use / land Cover Changes Using Remote Sensing and GIS in Rize, North-East Turkey. Sensors, 8, 6188-6202; DOI: 10.3390/s8106188.

[5] Cheruto Mercy C., Matheaus K. Kauti, Patrick D. Kisangau, Patrick Kariuki., 2016. Assessment of Land Use and Land Cover Change Using GIS and Remote Sensing Techniques: A Case Study of Makueni County, Kenya. J. Remote Sensing \& GIS, 5: 4; DOI: 10.4175/2469-4134.1000175.

[6] Botlhe Matlhodi, Piet K. Kenabatho, Bhagabat P. Parida, Joyce G. Maphanyane, 2019. Evaluating Land Use and Land Cover Change in the Gaborone Dam Catchment, Botswana, from 1984-2015 Using GIS and Remote Sensing. Sustainability 2019, 11, 5174; DOI: 10.3390/su11195174.

[7] Nithya P., Arulselvi G., 2019. Pattern Classification Technique to Assess Land Use/Cover Changes in Granite Quarry Area of Dharmapuri and Krishnagiri Districts of amilnadu. International Journal of Innovative Technology and Exploring Engineering (IJITEE) ISSN: 2278-3075, Volume-8 Issue 12, pp 2949.

[8] Daya N. P., Susane M. E., Groten P. S. R., 2000. Forest Vegetation / land use Change Detection and Impact Assessment in Part of Western Himalaya Indian. International Archives of Photogrammetry and Remote Sensing. Vol. XXXIII, Part B7. Amsterdam 2000. pp 1111.

[9] Karakus C. B., Orhan C., Kaan S. K., 2015. Determination of land used/cover changes and land use potentials of Sivas city and its surroundings using Geographical Information System (GIS) and Remote Sensing (RS). Procedia Earth and Planetary. 
[10] Cheng Y., Nie J., Li G., Zhang C., Wang W., 2008. "Study on Land use and Land Cover Change with the Integration of RS, GIS and GPS Technologies-The Case of Baotou City in the Ecotone of Agriculture Animal Husbandry, China", Geoscience and Remote Sensing Symposium, 2008. IGARSS 2008. IEEE International IEEE, pp. IV.

[11] Moeletsi R. S, Tesfamichael S. G., 2015. Assessing Land Cover Changes Caused By Granite Quarrying Using Remote Sensing. The International Archives of the Photogrammetry, Remote Sensing and Spatial Information Sciences, Volume XLII-3/W2, $201737^{\text {th }}$ International Symposium on Remote Sensing of Environment, 8-12 May 2017, Tshwane, South Africa.

[12] Nkechinyere V., 2010. Environmental sustainability and sustainable growth: A global outlook. Thesis in Organizational Dynamics at the University of Pennsylvania. P. 1 .

[13] Carla K., Christine M., Rita E., Souha T., 2014. Mediterranean Quarry Rehabilitation Manual: Learning from the Holcim Experience. P. 8. Nkechinyere V., 2010. Environmental sustainability and sustainable growth: A global outlook. Thesis in Organizational Dynamics at the University of Pennsylvania. P. 1.
[14] Meyer W. B. and Turner B. L., 1992. "Human population growth and global land-use/cover change", Annual Review of Ecology and Systematics. pp. 39-61.

[15] Koruyan K., Deliormanli H., Karaca Z., Momayez M., Lu H., Yalçin E., 2012. 'Remote sensing in management of mining land and proximate habitat', Journal of the Southern African Institute of Mining and Metallurgy, 112 (7), pp. 667-672.

[16] Loveland, Thomas. R., Dwyer, John. L. (2012). Landsat: Building a strong future. Journal of Remote Sensing of Environment, 122, 22-29. doi: 10.1016/j.rse.2011.09.022. do/10.1016/j.rse.2011.09.022

[17] Wulder M. A., White J. C., Goward S. N., Masek J. G., Irons J. R., Herold M., Cohen W. B., Loveland T. R., Woodcock C. E. (2008). 'Landsat continuity: Issues and opportunities for land cover monitoring', Remote Sensing of Environment, 112 (3), pp. 955-969.

[18] Ngon Ngon., 2007. Etude morphologique, minéralogique, géochimique et cristallographique des argiles latéritiques et des argiles hydromorphes de la région de Yaoundé en zone tropicale humide. Essais industriel et evaluation de leurs potentialités comme matériaux de construction. Thèse de doctorat $/ \mathrm{PhD}$ en science de la terre, Université de Yaoundé I. P. 77-80. 